\title{
Pharmacokinetics of single- and multiple-dose roflumilast: an open-label, three-way crossover study in healthy Chinese volunteers
} This article was published in the following Dove Press journal:
Drug Design, Development and Therapy

\author{
Jie Huang ${ }^{1,2, *}$ \\ Cheng-xiao $\mathrm{Fu}^{1,2, *}$ \\ Xiao-yan Yang ${ }^{1,2}$ \\ Chan Cui ${ }^{1,2}$ \\ Shuang Yang ${ }^{1,2}$ \\ Yun Kuang ${ }^{1,2}$ \\ Cheng-xian Guo ${ }^{1,2}$ \\ Pei $\mathrm{Hu}^{3}$ \\ $\mathrm{Qi} \mathrm{Pei}^{2,4}$ \\ Guo-ping Yang ${ }^{1,2}$
}

'Center of Clinical Pharmacology, The Third Xiangya Hospital, Central South University, Changsha, Hunan 4I00I3, People's Republic of China; ${ }^{2}$ Center for Clinical Drug Evaluation, Central South University, Changsha, Hunan 4 I00 I3, People's Republic of China; ${ }^{3}$ Clinical Pharmacology Research Center, Peking Union Medical College Hospital, Beijing I00032, People's Republic of China; ${ }^{4}$ Department of Pharmacy, The Third Xiangya Hospital, Central South University, Changsha, Hunan 4I00I3, People's Republic of China

*These authors contributed equally to this work

Correspondence: Guo-ping Yang; Qi Pei The Third Xiangya Hospital, Central South University, Yinpenling Street, Yuelu district, Changsha, Hunan 4I00I3, People's Republic of China

Tel +86 I 39748 I 7|68

Fax +8673188618326

Email ygp9880@I63.com; peiqil028@I26.com
Purpose: To determine the pharmacokinetic properties of the common tablet of roflumilast administered in single and multiple oral doses in Chinese subjects.

Subjects and methods: Both the single- and multiple-dose studies included 12 adults ( 6 males and 6 females). In this single-center, open-label study, single doses of $0.25,0.375$, and $0.5 \mathrm{mg}$ were administered using a randomized, three-way crossover design, and then, the $0.375 \mathrm{mg}$ dose was continued for 11 days once daily. The pharmacokinetic parameters for roflumilast and roflumilast $N$-oxide were determined and the safety evaluation included adverse events assessed by monitoring, physical examination, vital sign tests, and clinical laboratory tests.

Results: After every single dose, the time to the maximum concentration $\left(C_{\max }\right)$ of roflumilast $\left(T_{\max }\right)$ was $0.25-2.0$ hours; thereafter, the concentration declined, with a mean half-life $\left(t_{1 / 2}\right)$ of 19.7-20.9 hours over the range of $0.25-0.50 \mathrm{mg}$. As for roflumilast $N$-oxide, the mean $t_{1 / 2}$ was 23.2-26.2 hours. The area under curve from the beginning to 24 hours $\left(\mathrm{AUC}_{0-24 \mathrm{~h}}\right)$, the AUC until infinity ( $\mathrm{AUC}_{\text {inf }}$ ), and the $C_{\max }$ of roflumilast and roflumilast $N$-oxide increased in a dose-proportional manner. After multiple doses, the accumulation index $\left(\mathrm{R}_{\mathrm{ac}}\right)$ on the 11th day of the steady state was $\sim 1.63$ for roflumilast and 3.20 for roflumilast $N$-oxide. No significant sex differences were observed in the pharmacokinetic parameters of roflumilast and roflumilast $\mathrm{N}$-oxide. In addition, there were no serious adverse events across the trial.

Conclusion: Roflumilast was safe and well-tolerated in healthy volunteers, and a linear increase in its $C_{\max }$ and AUC values was observed at doses ranging from 0.25 to $0.50 \mathrm{mg}$.

Keywords: pharmacokinetics, roflumilast, roflumilast $N$-oxide, healthy volunteer, phosphodiesterase 4 inhibitor

\section{Introduction}

Roflumilast is a benzamide compound designed for the treatment of asthma and COPD. ${ }^{1-5}$ A phosphodiesterase 4 (PDE4) inhibitor (Figure 1A) is extensively metabolized by I (cytochrome [CYP]450) and II phase (conjugation) reactions. ${ }^{6}$ The only major metabolite of roflumilast found in human plasma is roflumilast $N$-oxide (Figure 1B), whose formation is mainly catalyzed by CYP3A4. Although roflumilast is three times more potent than roflumilast $N$-oxide upon the inhibition of the PDE4 enzyme in vitro, ${ }^{7}$ the plasma area under the curve (AUC) of roflumilast $N$-oxide on average is $\sim 10$-fold greater than that of roflumilast. ${ }^{8}$ After oral administration of a $0.5 \mathrm{mg}$ dose of roflumilast, its absolute bioavailability was $\sim 80 \%$. The maximum concentration $\left(C_{\max }\right)$ for roflumilast and roflumilast $N$-oxide is usually observed at $\sim 1$ hour (range $0.5-2$ hours) and 8 hours (range 4-13 hours) after administration, respectively. Food intake does not affect the total inhibitory activity of PDE4, ${ }^{9}$ but delays the time to the $C_{\max }$ of roflumilast $\left(T_{\max }\right)$ 
A

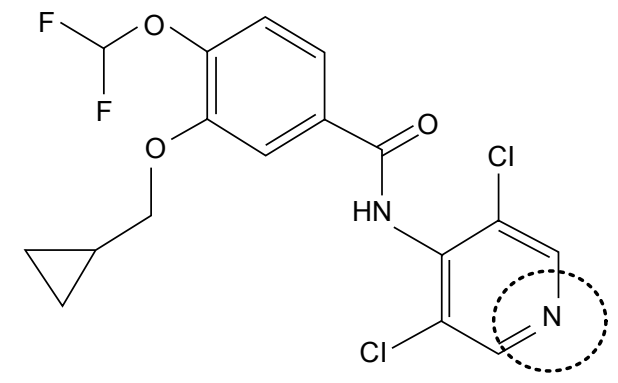

Figure I The chemical structure of roflumilast and roflumilast $\mathrm{N}$-oxide. Notes: (A) Roflumilast. (B) Roflumilast N-oxide.

by 1 hour and decreases $C_{\max }$ by $\sim 40 \%$. However, the $C_{\max }$ and $T_{\max }$ of roflumilast $N$-oxide are not influenced at all. The effective half-life $\left(t_{1 / 2}\right)$ ranges from 8 to 31 hours after dosing of $0.5 \mathrm{mg}$ roflumilast; thus, these findings support a daily dosing regimen of roflumilast.

However, to our knowledge, there is little literature about the pharmacokinetics of roflumilast and roflumilast $N$-oxide in healthy Chinese subjects. ${ }^{10,11}$ As a result, it is important to investigate the pharmacokinetics of these two compounds. This study was designed to evaluate the pharmacokinetics of roflumilast and roflumilast $N$-oxide in healthy Chinese volunteers.

\section{Subjects and methods Eligibility}

A total of 12 healthy Chinese volunteers including six males and six females were screened for inclusion. The volunteers were aged between 18 and 45 years, with a body mass index (BMI) of 19-24 kg/m². The minimum body weight was 45 and $50 \mathrm{~kg}$ for females and males, respectively. None of the volunteers had significant cardiac, hepatic, renal, pulmonary, neurologic, gastrointestinal, or hematologic disorders, as confirmed by performing a physical examination. Besides, those who had abused alcohol in the past 6 months or those who smoked heavily (more than five cigarettes a day) 3 months prior to the study were excluded. The study was conducted at a Phase I clinical center in the Third Xiangya Hospital of Central South University. It was conducted in accordance with the ethical standards for human studies of the Declaration of Helsinki and its amendments, ${ }^{12}$ the International Conference on Harmonization Guideline for Good Clinical Practice, ${ }^{13}$ and the Guideline for Good Clinical Principles recommended by the SFDA. ${ }^{14}$ The study protocol and informed consent form were approved by the ethics committee of The Third Xiangya Hospital of Central
B

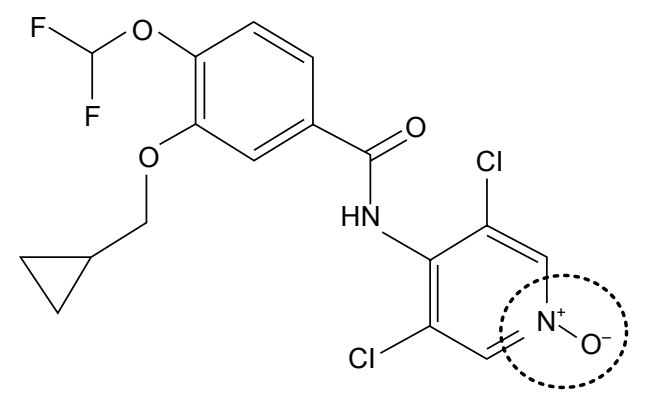

University. All participants were informed of the aim and risks by a clinical investigator, and each submitted written informed consent before participating in the study.

\section{Study drug}

Roflumilast tablets ( $0.25 \mathrm{mg}$, No 150101C, expiration date: January 2017; $0.375 \mathrm{mg}$, No 150101B, expiration date: January 2017; $0.5 \mathrm{mg}$, No 150101A, expiration date: January 2017) were manufactured and provided by Sichuan Baili Pharmaceutical Industry (Sichuan, P.R. China).

\section{Study design and drug administration}

This was a randomized, single-center, open-label trial based on a flowchart (Figure 2) wherein the pharmacokinetics of single and multiple oral administration of roflumilast were studied. A single-dose pharmacokinetic test was in the form of $3 \times 3$ Latin square crossover design. The subjects were admitted to the I phase ward one night before each cycle trial and fasted for more than 10 hours before the treatment. Then, a single dose of $0.25,0.375$, and $0.5 \mathrm{mg}$ was administrated in the morning on the first day of each study period. The single dose was $0.25,0.375$, or $0.5 \mathrm{mg}$ coupled with $250 \mathrm{~mL}$ of boiled water. The patients were not allowed to drink water 2 hours before and after dosing. Four and 10 hours after dosing, standard lunch and dinner, respectively, were allowed. After the completion of the single-dose test, multiple doses of $0.375 \mathrm{mg}$ were administrated once daily for 11 days continuously.

\section{Blood collection}

For the single-dose test, blood samples were collected from the cubital vein before dosing and $0.25,0.5,0.75,1,1.5,2.5$, $3,4,6,8,10,12,14,24,30,36,48,72$, and 96 hours after dosing. The washout period for each group was 10 days. For the multiple-dose test, blood samples were collected before 


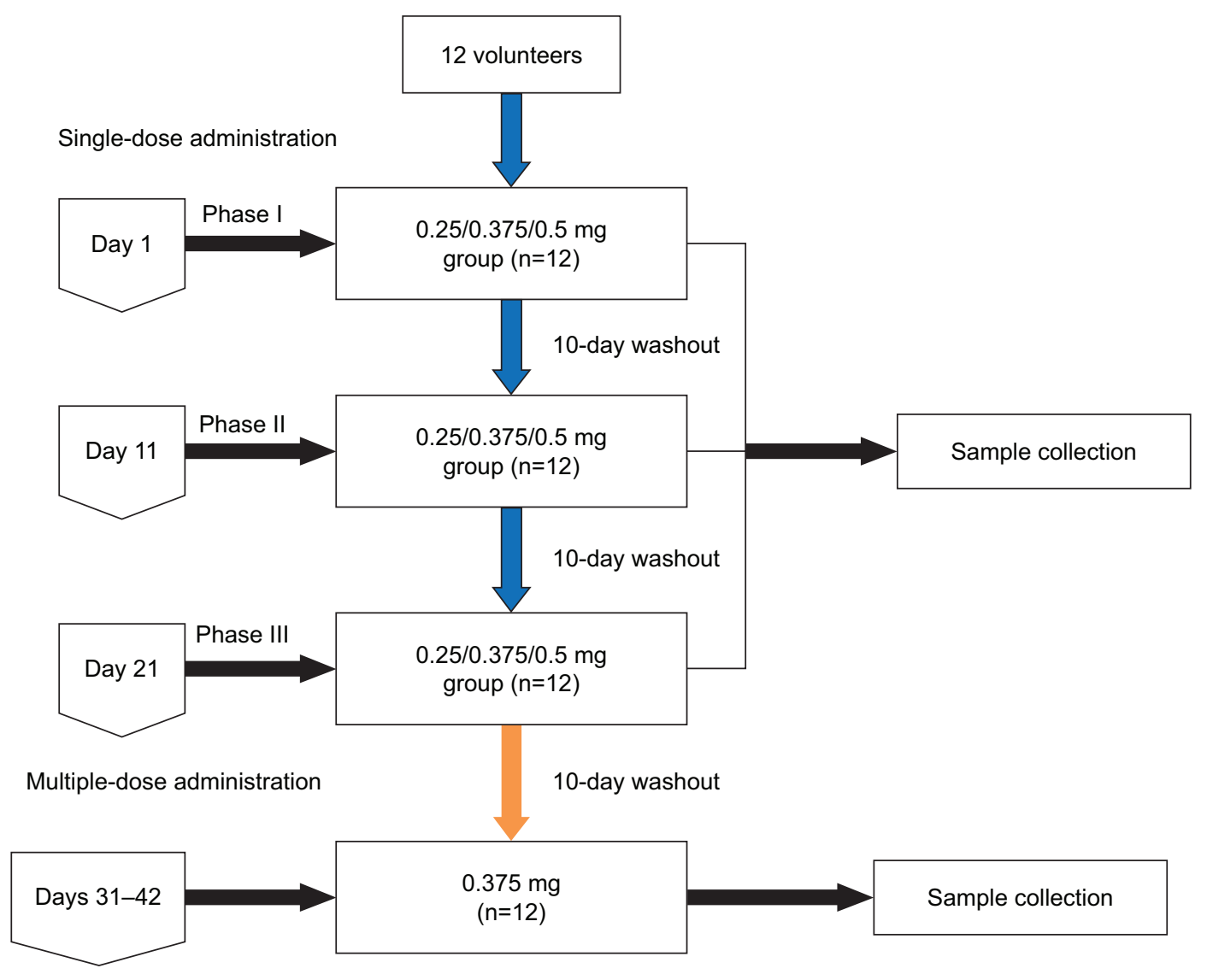

Figure 2 Flowchart of the study design. Blank indicating three phases of single-dose trial and multiple-dose trial until sample collection.

Notes: The blue arrow indicates 12 volunteers divided into randomized three doses groups, experiencing 10 -day washout. Yellow arrow indicates 12 subjects entering into multiple trial after 10-day washout with the last single-dose administration.

dosing and $0.25,0.5,0.75,1,1.5,2,2.5,3,4,6,8,10,12,14$, $24,30,36,48,72,96$ hours after dosing on the 11 th day.

\section{Sample preparation}

A volume of $5 \mathrm{~mL}$ of blood was collected into heparinized tubes and centrifuged at $2,700 \mathrm{rpm}$ at $4^{\circ} \mathrm{C}$ for 10 minutes. The collected plasma was transferred to Eppendorf tubes, which were maintained at $-70^{\circ} \mathrm{C}$ until the concentration analysis.

\section{Analytical assays}

High-performance liquid chromatography-tandem mass spectrometry was used to determine the concentration of $\mathrm{N}$-oxide in the samples at different time points after administration. ${ }^{15}$ An LC-MS/MS quantitation method was developed to simultaneously determine roflumilast and roflumilast $N$-oxide in human plasma with rather low limits of quantitation $\left(0.02 \mathrm{ng} \mathrm{mL}^{-1}\right.$ for roflumilast and $0.04 \mathrm{ng} \mathrm{mL}^{-1}$ for roflumilast $N$-oxide). Human plasma samples were prepared by solidphase extraction, which ensured high recovery and slight matrix effect for both analyses. In each validation batch, the calibration standards were analyzed and the calibration curve was linear within the range of $0.02-10 \mathrm{ng} \mathrm{mL}^{-1}$ and 0.04-50 ng mL $\mathrm{mL}^{-1}$ for roflumilast and roflumilast $N$-oxide, respectively. The regression coefficients of all the calibration curves were $>0.99$. The average bias among lower quality control (LQC), middle quality control (MQC), and higher quality control (HQC) samples was $<15 \%$ compared with the nominal concentration, and the coefficient of variation (CV) of each concentration level was $<15 \%$ as well, both for interrun precision and intra-run precision. The developed method was successfully applied for the pharmacokinetic research in Chinese healthy volunteers after oral administration of $0.25,0.375$, and $0.5 \mathrm{mg}$ roflumilast tablet.

\section{Safety assessment}

Safety was assessed according to interviews and adverse event (AE) monitoring. Vital sign tests, physical examinations, clinical laboratory tests, and electrocardiography were performed for each subject at screening and at study completion. AEs were assessed by direct observation, by using spontaneous 
reports, and by nonspecific inquiry and their clinical significance was determined by the monitoring physician. All information, including symptoms and signs before and after dosing were recorded in case report forms by investigators regardless of whether a relationship with the study drug was suspected.

\section{Pharmacokinetic analysis}

First, the pharmacokinetic analysis was performed by noncompartmental analysis using WinNonlin version 6.3 (Pharsight Corporation, Mountain View, CA, USA). Plasma roflumilast and roflumilast $N$-oxide concentrations vs time data after single-dose administration included $C_{\max }$ and $T_{\max }$. The AUC from the beginning to the last values $\left(\mathrm{AUC}_{\text {last }}\right)$ was determined using the linear trapezoidal method as was the $\mathrm{AUC}_{0-24 \mathrm{~h}}$, which indicated the AUC from the beginning to 24 hours. The first-order rate decline constant $\left(\lambda_{z}\right)$ for roflumilast plasma concentrations in the terminal phase of the concentration-time curve was determined using log-linear regression, and the $t_{1 / 2}$ was estimated from $\ln 2 / \lambda_{\mathrm{z}}$. $\mathrm{AUC}_{\mathrm{inf}}$ was determined using the following equation: $\mathrm{AUC}_{\text {last }}+C_{\text {last }} / \lambda_{\mathrm{z}}$. Clearance rate $(\mathrm{CL} / \mathrm{F})$ was estimated as dose divided by $\mathrm{AUC}_{\text {inf }}$, and the volume of distribution $(\mathrm{V} / \mathrm{F})$ was determined by dividing the apparent $\mathrm{CL} / \mathrm{F}$ by $\lambda_{\mathrm{z}}$. The multiple-dose study provided $T_{\max }$ at steady state $\left(T_{\text {max }, \mathrm{ss}}\right), C_{\max }$ at steady state $\left(C_{\text {max,ss }}\right)$, and minimum plasma concentration at steady state $\left(C_{\text {min,ss }}\right)$. The accumulation index was determined as $\mathrm{AUC}_{0-24 \mathrm{~h}}$ (day 11) $/ \mathrm{AUC}_{0-24 \mathrm{~h}(\text { day } 1)}$, while the degree of fluctuation (DF) was calculated as $\left(C_{\text {max,ss }}-C_{\text {min,ss }}\right) / C_{\text {avg }}$, where $C_{\text {avg }}$ was the average steady-state drug concentration during multiple-dosing intervals, which was calculated as $\mathrm{AUC}_{\tan , \mathrm{Ss}} / \tan$, where tan was the dosing interval for 24 hours. The $t_{1 / 2}, \mathrm{CL} / \mathrm{F}$, and V/F at steady state were determined using the same method as that used for the single-dose study.

In addition, pharmacokinetic analyses were performed by compartmental analysis using WinNonlin version 6.3. Nonlinear least squares regression analysis was performed using the plasma roflumilast and roflumilast $\mathrm{N}$-oxide concentration vs time data. One and two compartment models with zero-order input and first-order elimination from the central compartment were fitted to the data. Data were weighted by the reciprocal of the observed plasma. The best-fitting model was selected by observing the residual plot, and by using Akaike's information criterion. The model estimated the apparent volume of the central compartment $\left(\mathrm{V}_{1} / \mathrm{F}\right), \mathrm{T}_{\mathrm{lag}}$, $\mathrm{K}_{21}, \mathrm{~K}_{12}, \mathrm{~K}_{01}$, and $\mathrm{K}_{10}$. Data are reported as medians (SD).

\section{Statistical analyses}

Statistical analyses were performed using SPSS version 18.0. All data were expressed as mean \pm SD values. Logtransformed pharmacokinetic parameters $\mathrm{AUC}_{0-24 \mathrm{~h}}, \mathrm{AUC}_{\text {inf }}$, and $C_{\max }$ were analyzed to determine dose proportionality using the power model, $\mathrm{PK}=\mathrm{A} \times(\text { dose })^{\beta}$, where $\mathrm{PK}$ was the pharmacokinetic parameter, $\mathrm{A}$ was the intercept, and $\beta$ was the dose-proportionality coefficient. In case the $90 \% \mathrm{CI}$ for the dose-proportionality parameter $\beta$ was included in the estimation interval, the pharmacokinetic parameters would correspond to perfect dose proportionality. Pharmacokinetic parameters were compared among dose levels by using ANOVA, including sex-related differences. A $P$-value of $<0.05$ was considered significant.

\section{Results}

\section{Demographic characteristics}

Twelve healthy Chinese volunteers (Table 1) with the following characteristics were enrolled in this study: age, $21 \pm 3$ years (range, 18.0-27.0 years); weight, $61.3 \pm 5.4 \mathrm{~kg}$ (range, $47.0-73.5 \mathrm{~kg}$ ); and height, $171 \pm 4 \mathrm{~cm}$ (range, 153-176 cm). All participants completed the study and were included in the PK analysis.

\section{Noncompartmental analysis of single-dose administration}

The mean plasma concentration vs time profiles for roflumilast and roflumilast $N$-oxide after administration of a single dose of $0.25,0.375$, or $0.50 \mathrm{mg}$ were shown in Figure 3 . The shape of the curves was similar between the various dose groups. As shown in Table 2, the mean $T_{\max }$ values for roflumilast among the three dose groups were within $0.25-2.0$ hours. The mean $t_{1 / 2}$ values of roflumilast and roflumilast $N$-oxide were $\sim 20$ and 25 hours, respectively. The differences in $t_{1 / 2}$ and $\mathrm{CL} / \mathrm{F}$ among these dose groups were not statistically significant $(P>0.05)$. Furthermore,

Table I Baseline demographic characteristics of study volunteers $(n=12)$

\begin{tabular}{|l|l|l|l|l|}
\hline \multirow{2}{*}{} & \multicolumn{4}{l|}{ Mean \pm SD (relative standard deviation) } \\
\cline { 2 - 5 } & Age (years) & Height $(\mathbf{c m})$ & Weight $(\mathbf{k g})$ & BMI $\left(\mathbf{k g} / \mathbf{m}^{2}\right)$ \\
\hline Males $(\mathrm{n}=6)$ & $24 \pm I(4.0 \%)$ & $17 I \pm 4(2.33 \%)$ & $62.4 \pm 7.1(I I .4 \%)$ & $21.3 \pm 2.2(I 0.3 \%)$ \\
Females $(\mathrm{n}=6)$ & $2 I \pm 4(19.0 \%)$ & $157 \pm 5(3.18 \%)$ & $53.7 \pm 6.7(I 2.5 \%)$ & $21.7 \pm 2.2(10.1 \%)$ \\
\hline
\end{tabular}

Abbreviations: BMl, body mass index; $\mathrm{n}$, sample size. 

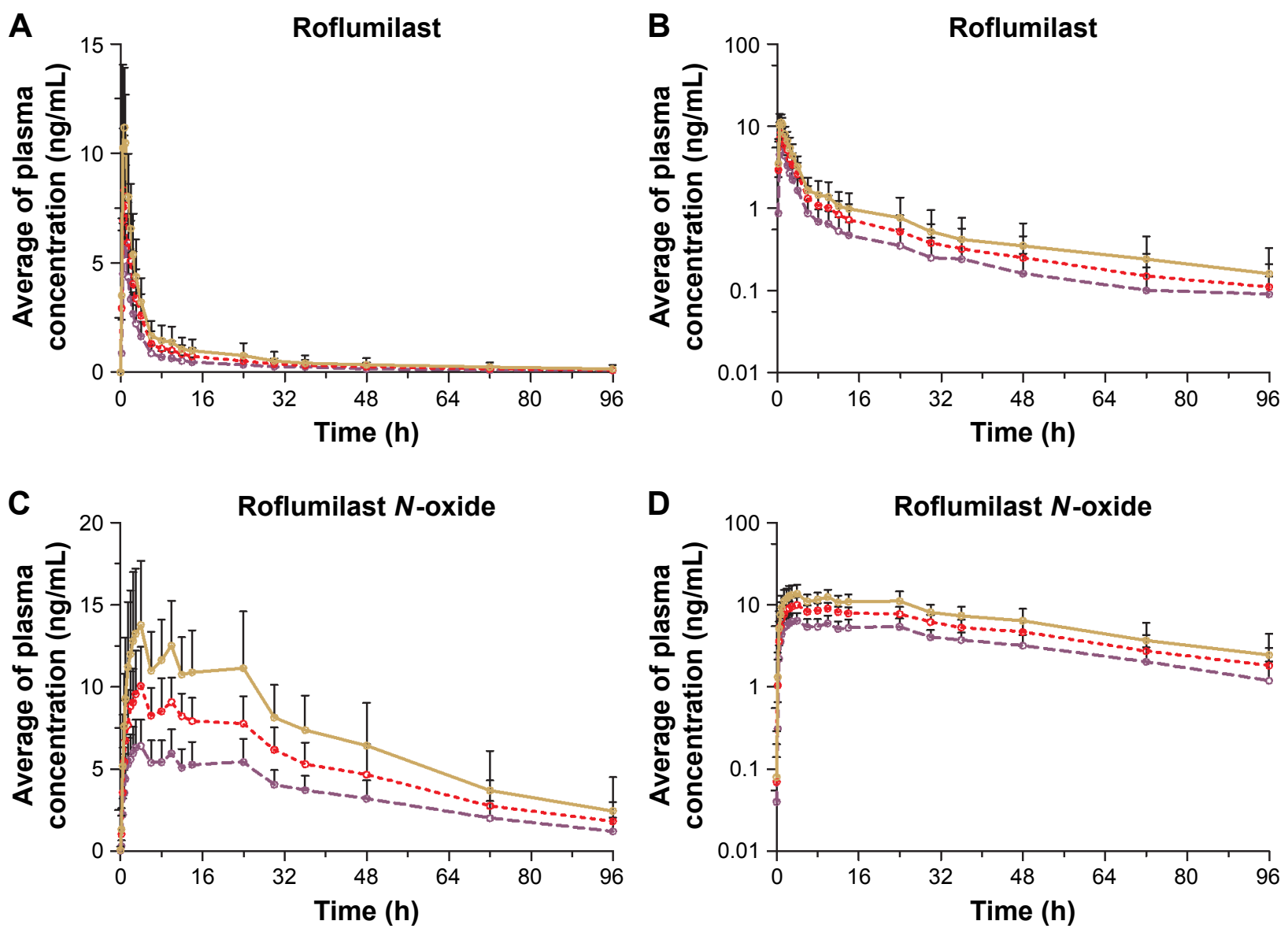

$$
-0.25 \mathrm{mg} \quad-0.375 \mathrm{mg}=0.5 \mathrm{mg}
$$

Figure 3 Mean (SD) plasma concentration-time curves of roflumilast and roflumilast $\mathrm{N}$-oxide following $0.25,0.375$, and $0.5 \mathrm{mg}$ single dose in ordinary coordinates and semi-log coordinates.

Notes: (A) Ordinary coordinates curves for roflumilast. (B) Semi-log coordinates curves for roflumilast. (C) Ordinary coordinates curves for roflumilast N-oxide. (D) Semilog coordinates curves for roflumilast $\mathrm{N}$-oxide.

Table 2 Pharmacokinetic parameters of the roflumilast and roflumilast $\mathrm{N}$-oxide after single dose

\begin{tabular}{|c|c|c|c|c|}
\hline \multirow[t]{2}{*}{ Analytes } & \multirow[t]{2}{*}{ Parameters } & \multicolumn{3}{|l|}{ Dose } \\
\hline & & $0.25 \mathrm{mg}$ & $0.375 \mathrm{mg}$ & $0.5 \mathrm{mg}$ \\
\hline \multirow[t]{9}{*}{ Roflumilast } & $\mathrm{AUC}_{0-24 \mathrm{~h}}\left(\mathrm{~h} \mathrm{ng} \mathrm{mL^{-1 } )}\right.$ & $24.1(8.2)$ & $35.70(12.0)$ & $47.9(16.3)$ \\
\hline & $A \cup C_{\text {inf }}\left(h \mathrm{ng} \mathrm{mL}^{-1}\right)$ & $33.8(17.3)$ & $48.70(23.4)$ & $65.1(34.4)$ \\
\hline & $\mathrm{AUC}_{\text {last }}\left(\mathrm{h} \mathrm{ng} \mathrm{mL^{-1 } )}\right.$ & $33.4(15.8)$ & $49.4(22.8)$ & $67.5(35.0)$ \\
\hline & $\mathrm{CL} / \mathrm{F}\left(\mathrm{L} \mathrm{h}^{-1}\right)$ & $9.2(4.5)$ & $9.3(4.0)$ & $9.5(4.3)$ \\
\hline & $C_{\max }\left(\mathrm{ng} \mathrm{mL}^{-1}\right)$ & $6.4(1.1)$ & $9.2(1.9)$ & $12.5(2.9)$ \\
\hline & $\lambda_{z}\left(h^{-1}\right)$ & $0.04 \mid(0.0267)$ & $0.042(0.0247)$ & $0.0429(0.025 \mathrm{I})$ \\
\hline & $t_{1 / 2}(\mathrm{~h})$ & $20.9(7.6)$ & $19.7(6.4)$ & $19.9(7.7)$ \\
\hline & $* T_{\max }(\mathrm{h})$ & $0.75(0.50-1.50)$ & $0.50(0.25-2.00)$ & $0.75(0.50-1.50)$ \\
\hline & $\mathrm{V} / \mathrm{F}(\mathrm{L})$ & $243.0(94.7)$ & $237.0(82.3)$ & $234.0(70.4)$ \\
\hline \multirow[t]{7}{*}{ Roflumilast $\mathrm{N}$-oxide } & $\mathrm{AUC}_{0-24 \mathrm{~h}}\left(\mathrm{~h} \mathrm{ng} \mathrm{mL^{-1 } )}\right.$ & I $28.0(30.4)$ & $192.0(32.1)$ & $266.0(54.7)$ \\
\hline & $\mathrm{AUC}_{\mathrm{inf}}\left(\mathrm{h} \mathrm{ng} \mathrm{mL^{-1 } )}\right.$ & $333.0(103.0)$ & $493.0(148.0)$ & $649.0(189.0)$ \\
\hline & $\mathrm{AUC}_{\text {last }}\left(\mathrm{h} \mathrm{ng} \mathrm{mL^{-1 } )}\right.$ & $320.0(75.1)$ & $458.0(107.0)$ & $630.0(172.0)$ \\
\hline & $C_{\max }\left(\mathrm{ng} \mathrm{mL}^{-1}\right)$ & $6.7(1.7)$ & $10.4(2.1)$ & $14.7(3.7)$ \\
\hline & $\lambda_{z}\left(\mathrm{~h}^{-1}\right)$ & $0.031(0.00986)$ & $0.0284(0.0083)$ & $0.0317(0.0075)$ \\
\hline & $t_{1 / 2}(\mathrm{~h})$ & $24.3(7.4)$ & $26.2(7.4)$ & $23.2(6.7)$ \\
\hline & $T_{\max }(\mathrm{h})$ & $4.00(2.50-24.00)$ & $4.00(3.00-24.00)$ & $4.00(2.50-24.00)$ \\
\hline
\end{tabular}

Note: ${ }^{*} T_{\text {mx }}$ : median (min-max), the other parameters of pharmacokinetic: mean (SD).

Abbreviations: $A \cup C$, area under the curve; $A \cup C_{\text {inf }}, A \cup C$ until infinity; $A \cup C_{0-24}, A \cup C$ from the beginning to 24 hours; $A \cup C_{\text {last }}, A \cup C$ from the beginning to the last values; $C_{\max }$, maximum concentration; $t_{1 / 2}$, half-life; $T_{\max }$, the time to the $C_{\max }$ of roflumilast; CL/F, clearance rate; $\mathrm{V} / \mathrm{F}$, volume of distribution. 
Table 3 The comparison of pharmacokinetic parameters in different treatments and genders

\begin{tabular}{|l|l|l|l|}
\hline \multirow{2}{*}{ Factors } & \multicolumn{2}{|l|}{ Roflumilast } & $\begin{array}{l}\text { Roflumilast } \\
\text { N-oxide }\end{array}$ \\
\cline { 2 - 4 } & Parameters & P-value & P-value \\
\hline Dose & AUC $_{0-24 \mathrm{~h}}$ & - & - \\
& $\mathrm{C}_{\max }$ & - & - \\
& $\mathrm{CL} / \mathrm{F}$ & 0.905 & - \\
& $t_{1 / 2}$ & 0.870 & 0.324 \\
& & - & - \\
Gender & $\mathrm{AUC}_{0-24 \mathrm{~h}}$ & 0.824 & 0.814 \\
& $\mathrm{C}_{\max }$ & 0.402 & 0.973 \\
& $\mathrm{CL} / \mathrm{F}$ & 0.668 & - \\
& $t_{1 / 2}$ & 0.197 & 0.399 \\
\hline
\end{tabular}

Abbreviations: $A \cup C$, area under the curve; $\mathrm{AUC}_{0-24}$, $A \cup C$ from the beginning to 24 hours; $C_{\max }$, maximum concentration; $t_{1 / 2}$, half-life.

the differences in these main pharmacokinetic parameters between male and female patients were not statistically significant $(P>0.05)$ (Table 3$)$.

As shown in Table 4, the power model estimating the linearity of a single dose ranging from 0.25 to $0.50 \mathrm{mg}$ was analyzed. The $90 \%$ CIs for the slope of the relational equation were 0.869-1.103 $\left(C_{\max }\right), 0.930-1.099\left(\mathrm{AUC}_{0-24 \mathrm{~h}}\right)$, and 0.890-1.085 $\left(\mathrm{AUC}_{\mathrm{inf}}\right)$ for roflumilast, whereas those for roflumilast $N$-oxide were $1.020-1.198\left(C_{\max }\right), 0.984-1.116$ $\left(\mathrm{AUC}_{0-24 \mathrm{~h}}\right)$, and 0.852-1.059 (AUC $\left.\mathrm{inf}\right)$, all of which were within the estimation interval $(0.8,1.25)$. The pharmacokinetic parameters of roflumilast in the human body at a dose range of $0.25-0.50 \mathrm{mg}$ conformed to the linear pharmacokinetic process.

\section{Noncompartmental analysis of multiple-dose administration}

After multiple doses of roflumilast $0.375 \mathrm{mg}$ was administered over 11 days, the pharmacokinetic parameters $T_{\max }$ (0.75 vs $0.50, P>0.05), \mathrm{CL} / \mathrm{F}(8.6$ vs $9.4, P>0.05)$, and $C_{\max }$ (11.4 vs 9.2, $P>0.05$ ) for roflumilast were similar to those observed in the single-dose study. For roflumilast $N$-oxide, some pharmacokinetic parameters were relatively higher, such as $\mathrm{AUC}_{0-24 \mathrm{~h}}(618.0$ vs 192.0, $P<0.05), \mathrm{AUC}_{\text {inf }}(1,320.0$

Table 4 Dose proportionality following $0.25-0.5 \mathrm{mg}$ doses

\begin{tabular}{|c|c|c|c|}
\hline Analytes & Parameters & Slope $\beta(90 \% \mathrm{CI})$ & Criterion \\
\hline \multirow[t]{3}{*}{ Roflumilast } & $A \cup C_{0-24 \mathrm{~h}}$ & $1.011(0.930,1.099)$ & $(0.800,1.250)$ \\
\hline & $A \cup C_{i n f}$ & $0.983(0.890,1.085)$ & $(0.800,1.250)$ \\
\hline & $C_{\max }$ & $0.979(0.869,1.103)$ & $(0.800,1.250)$ \\
\hline Roflumilast & $\mathrm{AUC}_{0-24 \mathrm{~h}}$ & $1.048(0.984$, I.I I6) & $(0.800,1.250)$ \\
\hline \multirow[t]{2}{*}{$N$-oxide } & $A \cup C_{\text {inf }}$ & $0.950(0.852,1.059)$ & $(0.800,1.250)$ \\
\hline & $C_{\max }$ & I.I 05 (1.020, I.198) & $(0.800,1.250)$ \\
\hline
\end{tabular}

Abbreviations: $A \cup C$, area under the curve; $A \cup C_{\text {inf }} A \cup C$ until infinity; $A \cup C_{0-24 h}$, AUC from the beginning to 24 hours. vs 493.0, $P<0.05), \mathrm{AUC}_{\text {last }}(1,410.0$ vs $458.0, P<0.05)$, and $C_{\max }(35.4$ vs $10.4, P<0.05)$. In addition, the accumulation index $\left(\mathrm{R}_{\mathrm{ac}}\right)$ was around 1.63 for roflumilast and 3.20 for roflumilast $N$-oxide. The DF was $\sim 4.85$ for roflumilast and 0.56 for roflumilast $N$-oxide (Table 5 and Figure 4 ).

\section{Compartmental analysis of single- and multiple-dose administration}

According to statistical analysis and "goodness-of-fit" criteria, a weighted $\left(1 / \mathrm{Y}^{2}\right)$ two-compartment pharmacokinetic model was adopted to describe roflumilast activity in plasma, and a one-compartment pharmacokinetic model was adopted to describe roflumilast $N$-oxide activity in plasma following three single oral doses of $0.25,0.375$, and $0.5 \mathrm{mg}$ as well as multiple oral doses of $0.375 \mathrm{mg}$. The compartment pharmacokinetic parameters are summarized in Table 6 .

\section{Safety and tolerability}

As seen in Table 7, during the course of the single- and multiple-dose studies, a total of 48 treatment-related adverse events were noted, of which 19 were considered as certainly related to treatment; 5 , probably related to treatment; and 24, possibly related to treatment. Seven TRAEs were reported by

Table 5 Pharmacokinetic parameters of the roflumilast and roflumilast $\mathrm{N}$-oxide after multiple doses

\begin{tabular}{|c|c|c|}
\hline & Parameters & $0.375 \mathrm{mg}$ \\
\hline \multirow[t]{12}{*}{ Roflumilast } & $\mathrm{AUC}_{0-24 \mathrm{~h}}\left(\mathrm{~h} \mathrm{ng} \mathrm{mL^{-1 } )}\right.$ & $59.3(32.7)$ \\
\hline & $A \cup C_{\text {inf }}\left(\mathrm{h} \mathrm{ng} \mathrm{mL^{-1 } )}\right.$ & $81.4(49.7)$ \\
\hline & $\mathrm{AUC}_{\text {last }}\left(\mathrm{h} \mathrm{ng} \mathrm{mL^{-1 } )}\right.$ & $94.0(70.7)$ \\
\hline & $\mathrm{CL} / \mathrm{F}\left(\mathrm{L} \mathrm{h}^{-1}\right)$ & $8.6(4.0)$ \\
\hline & $C_{\text {avg }}\left(n g \mathrm{~mL}^{-1}\right)$ & $2.5(1.4)$ \\
\hline & $C_{\text {max ss }}\left(\mathrm{ng} \mathrm{mL} L^{-1}\right)$ & II.40 (3.6) \\
\hline & DF & $4.85(1.95)$ \\
\hline & $\lambda_{z}\left(h^{-1}\right)$ & $0.0298(0.00952)$ \\
\hline & $\mathrm{R}_{\mathrm{ac}}$ & I.63 (0.546) \\
\hline & $t_{1 / 2}(\mathrm{~h})$ & $25.6(8.5)$ \\
\hline & $* T_{\max }(\mathrm{h})$ & $0.75(0.50-2.50)$ \\
\hline & $\mathrm{V} / \mathrm{F}(\mathrm{L})$ & $329.0(269.0)$ \\
\hline Roflumilast & $A \cup C_{0-24 h}\left(h \mathrm{hg} \mathrm{mL}^{-1}\right)$ & $618.0(223.0)$ \\
\hline \multirow[t]{9}{*}{$N$-oxide } & $\mathrm{AUC}_{\text {inf }}\left(\mathrm{h} \mathrm{ng} \mathrm{mL^{-1 } )}\right.$ & I,320.0 (624.0) \\
\hline & $\mathrm{AUC}_{\text {last }}\left(\mathrm{h} \mathrm{ng} \mathrm{mL^{-1 }}\right)$ & I,4I $0.0(696.0)$ \\
\hline & $C_{\text {avg }}\left(\mathrm{ng} \mathrm{mL}^{-1}\right)$ & $25.8(9.3)$ \\
\hline & $C_{\text {max }, s s}\left(\mathrm{ng} \mathrm{mL}^{-1}\right)$ & $35.4(13.8)$ \\
\hline & DF & $0.56(0.13)$ \\
\hline & $\lambda_{z}\left(\mathrm{~h}^{-1}\right)$ & $0.0286(0.00636)$ \\
\hline & $\mathrm{R}_{\mathrm{ac}}$ & $3.20(1.37)$ \\
\hline & $t_{1 / 2}(\mathrm{~h})$ & $25.2(5.1)$ \\
\hline & $* T_{\max }(\mathrm{h})^{\mathrm{a}}$ & $3.00(1.00-4.00)$ \\
\hline
\end{tabular}

Note: ${ }^{*} T_{\text {max }}$ : median (min-max), the other parameters of pharmacokinetic: mean (SD). Abbreviations: AUC, area under the curve; $A \cup C_{\text {in }}$ AUC until infinity; $A_{U C}{ }_{0-24}, A \cup C$ from the beginning to 24 hours; $A \cup C_{\text {last }}$ AUC from the beginning to the last values; $C_{\text {avg }}$, the average steady-state drug concentration during multiple-dosing intervals; $C_{\text {max }}$, maximum concentration; DF, degree of fluctuation; $R_{a c}$, the accumulation index; $t_{1 / 2}$, half-life; $T_{\text {max }}$, the time to the $C_{\text {max }}$ of roflumilast; $\mathrm{V} / \mathrm{F}$, volume of distribution. 

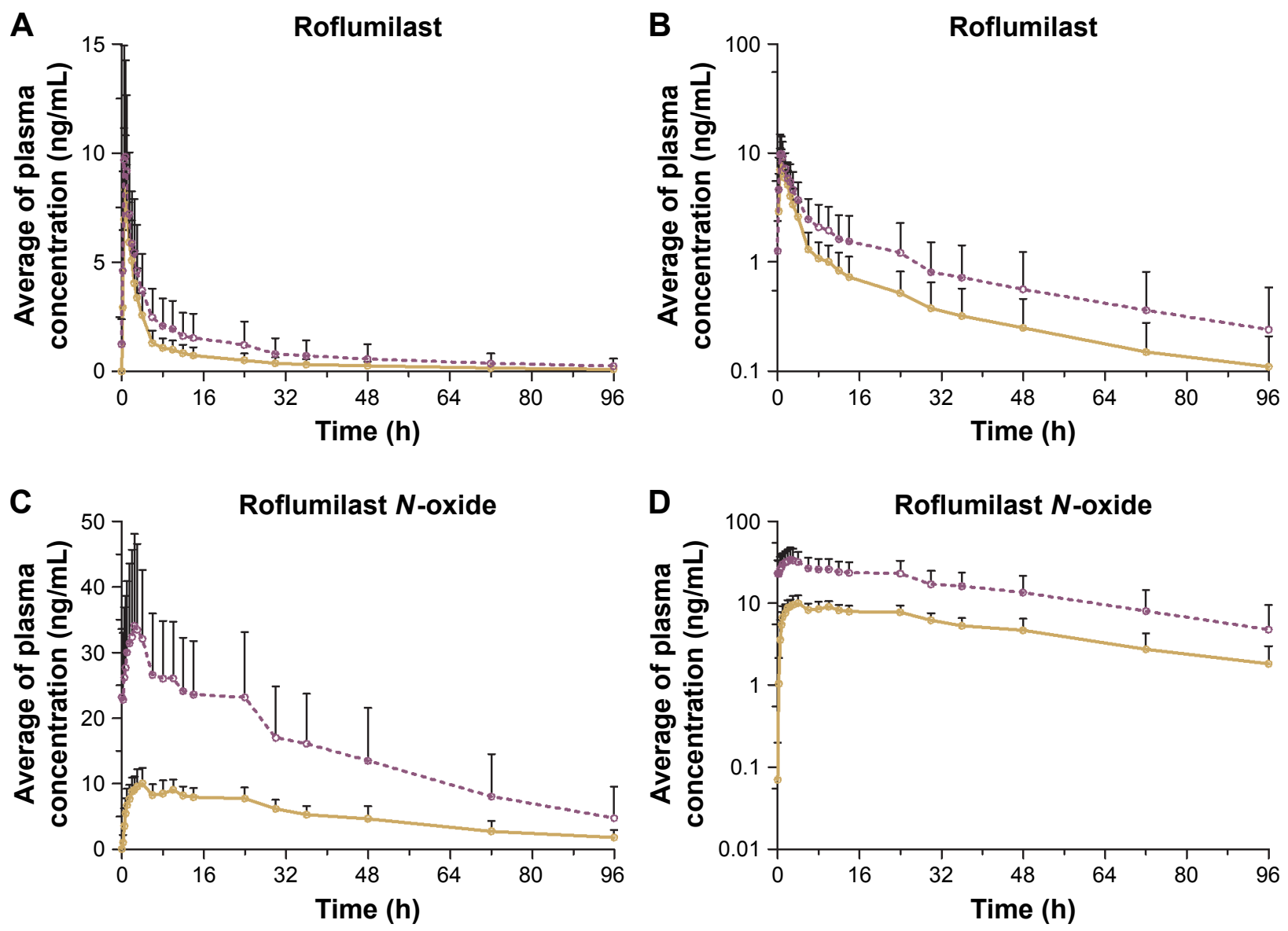

$\because$ Day $1-\infty$ - Day 11

Figure 4 Mean (SD) plasma concentration-time curves of roflumilast and roflumilast $\mathrm{N}$-oxide following 0.375 mg multiple doses.

Notes: (A) Ordinary coordinates curves for roflumilast. (B) Semi-log coordinates curves for roflumilast. (C) Ordinary coordinates curves for roflumilast $N$-oxide. (D) Semi-log coordinates curves for roflumilast $\mathrm{N}$-oxide.

four subjects while receiving the $0.25 \mathrm{mg}$ single dose, six by six subjects while receiving the $0.375 \mathrm{mg}$ single dose, 10 by six subjects while receiving the $0.50 \mathrm{mg}$ single dose, and 25 by 12 subjects while receiving $0.375 \mathrm{mg}$ multiple doses.

Dizziness (53.8\%), nausea (53.8\%), diarrhea (30.8\%), and headache $(23.1 \%)$ were the more common TRAEs. Fortysix TRAEs were of mild degree, whereas only one TRAE presenting as diarrhea was of severe degree, and one TRAE presenting as acute gastroenteritis was of moderate degree. All these TRAEs resolved without sequelae.

Table 6 The parameters of the two-compartment model of roflumilast and one-compartment model of roflumilast $\mathrm{N}$-oxide

\begin{tabular}{|c|c|c|c|c|c|}
\hline \multirow[t]{2}{*}{ Analytes } & \multirow[t]{2}{*}{ Parameters } & \multicolumn{3}{|l|}{ Single dose } & \multirow{2}{*}{$\begin{array}{l}\text { Multiple doses } \\
0.375 \mathrm{mg}\end{array}$} \\
\hline & & $0.25 \mathrm{mg}$ & $0.375 \mathrm{mg}$ & $0.5 \mathrm{mg}$ & \\
\hline \multirow[t]{6}{*}{ Roflumilast } & $\mathrm{K}_{01}\left(\mathrm{~h}^{-1}\right)$ & $12.746(13.6)$ & I5.270 (I3.344) & $15.196(16.558)$ & $14.782(10.327)$ \\
\hline & $\mathrm{K}_{10}\left(\mathrm{~h}^{-1}\right)$ & $0.259(0.092)$ & $0.258(0.124)$ & $0.254(0.115)$ & $0.205(0.057)$ \\
\hline & $\mathrm{K}_{12}\left(\mathrm{~h}^{-1}\right)$ & $0.324(0.112)$ & $0.310(0.14 I)$ & $0.300(0.101)$ & $0.292(0.168)$ \\
\hline & $\mathrm{K}_{21}\left(\mathrm{~h}^{-1}\right)$ & $0.101(0.033)$ & $0.096(0.038)$ & $0.097(0.036)$ & $0.082(0.036)$ \\
\hline & $\mathrm{T}_{\operatorname{lag}}(\mathrm{h})$ & $0.304(0.108)$ & $0.296(0.129)$ & $0.24 \mid(0.033)$ & $0.283(0.103)$ \\
\hline & $\mathrm{V}_{\mathrm{l}} / \mathrm{F}(\mathrm{L})$ & $33.148(6.036)$ & 35.031 (8.793) & $35.02(8.804)$ & $35.721(10.918)$ \\
\hline \multirow[t]{4}{*}{ Roflumilast $\mathrm{N}$-oxide } & $\mathrm{K}_{01}\left(\mathrm{~h}^{-1}\right)$ & I.486 (0.499) & $1.748(1.058)$ & $\mathrm{I} .440(0.63 \mathrm{I})$ & $2.422(1.686)$ \\
\hline & $\mathrm{K}_{10}\left(\mathrm{~h}^{-1}\right)$ & $0.020(0.012)$ & $0.021(0.012)$ & $0.021(0.012)$ & $0.024(0.008)$ \\
\hline & $\mathrm{T}_{\mathrm{lag}}(\mathrm{h})$ & $0.260(0.112)$ & $0.246(0.150)$ & $0.213(0.082)$ & $0.232(0.182)$ \\
\hline & $V_{1} / F(L)$ & $40.13(12.686)$ & $37.566(9.235)$ & $37.402(10.657)$ & $29.230(8.373)$ \\
\hline
\end{tabular}

Notes: Parameters: mean (SD). $\mathrm{K}_{01}$ : rate constant from the absorption chamber into the central chamber; $\mathrm{K}_{10}$ : elimilation rate constant of the central chamber; $\mathrm{K}_{12}$ : transportion rate constant from the central chamber into the peripheral chamber; $\mathrm{K}_{21}$ : transportion rate constant from the peripheral chamber into the central chamber; $\mathrm{T}_{\text {lag }}$ : lag time; $\mathrm{V}_{\mathrm{I}} / \mathrm{F}$ : apparent volume of the central compartment. 
Table 7 Number of subjects (\%) reporting treatment-related adverse events (TRAEs) following single and multiple doses of roflumilast

\begin{tabular}{|c|c|c|c|c|c|c|}
\hline & \multicolumn{3}{|c|}{ Single dose $(n=12 / 13)$} & \multirow{2}{*}{$\begin{array}{l}\text { Multiple doses } \\
(n=\mid 2)\end{array}$} & \multirow{2}{*}{$\begin{array}{l}\text { Total TRAEs } \\
(n=48)\end{array}$} & \multirow{2}{*}{$\begin{array}{l}\text { Total subjects } \\
(n=\mid 3)\end{array}$} \\
\hline & $0.25 \mathrm{mg}(\mathrm{n}=12)$ & $0.375 \mathrm{mg}(\mathrm{n}=13)$ & $0.50 \mathrm{mg}(\mathrm{n}=13)$ & & & \\
\hline Any adverse event & $4(33.3)$ & $6(46.2)$ & $8(61.5)$ & $12(100)$ & & \\
\hline Dizziness & $3(25)$ & $2(15.4)$ & $5(38.5)$ & $5(4 \mid .7)$ & 15 & $7(53.8)$ \\
\hline Nausea & & & I (7.7) & $6(50.0)$ & 7 & $7(53.8)$ \\
\hline Headache & I (8.3) & I (7.7) & I (7.7) & $4(33.3)$ & 7 & $3(23.1)$ \\
\hline Diarrhea & & & & $4(33.3)$ & 4 & $4(30.8)$ \\
\hline Upper respiratory infection & & & & $2(16.7)$ & 2 & $3(23.1)$ \\
\hline Increased total bilirubin & $\mathrm{I}(8.3)$ & I (7.7) & & & 2 & $2(15.4)$ \\
\hline Chest distress & I (8.3) & & I (7.7) & & 2 & I (7.7) \\
\hline Elevated creatine kinase & $\mathrm{I}(8.3)$ & & & I (8.3) & 2 & $2(15.4)$ \\
\hline Potassium reduction & & & I (7.7) & & I & I (7.7) \\
\hline Fatigue & & & & I (8.3) & 1 & I (7.7) \\
\hline Loss of appetite & & & I (7.7) & & I & I (7.7) \\
\hline Elevated uric acid & & I (7.7) & & & 1 & I (7.7) \\
\hline Acute gastroenteritis & & & & I (8.3) & I & I (7.7) \\
\hline Proteinuria & & I (7.7) & & & I & I (7.7) \\
\hline Back pain in the right side & & & & I (8.3) & I & I (7.7) \\
\hline Related to drug & & & & & & \\
\hline Certainly & 19 & & & & & \\
\hline Probably & 5 & & & & & \\
\hline Possibly & 24 & & & & & \\
\hline
\end{tabular}

\section{Discussion}

COPD is a crucial factor causing morbidity and mortality and has a substantial global economic and social burden. The present approach for the management of COPD involves initial treatment with bronchodilators, followed by inhaled steroids when required. However, many patients still experience exacerbations despite access to the currently available therapy. ${ }^{16}$

A previous study ${ }^{17}$ confirmed that oral roflumilast at doses of $0.10,0.25$, and $0.50 \mathrm{mg}$ once daily showed statistically significant effects with dose-related increases from baseline based on forced expiratory volume in 1 second in patients with asthma. It is clear that roflumilast at $0.50 \mathrm{mg}$ once daily is more effective than lower doses with well tolerance. In a randomized double-blind controlled trial of roflumilast treatment for acute exacerbations of COPD,${ }^{18}$ patients treated with roflumilast over 4 weeks experienced a statistically significant greater reduction in the percentage of sputum neutrophils and sputum myeloperoxidase concentration, which tended to have beneficial effects on lung function.

As seen in Table 8, Bethke et $\mathrm{al}^{11}$ used a two-period, twosequence crossover study in 15 subjects receiving immediaterelease tablets of roflumilast 0.25 or $0.5 \mathrm{mg}$ to investigate the single-dose pharmacokinetics of the drug. However, that study was based on Caucasians. Moreover, the previous literature, ${ }^{10}$ which described a parallel-group study conducted in healthy Chinese subjects, did not show considerable dose-proportional pharmacokinetic characteristics because of interindividual variability. This article used a $3 \times 3$ Latin square crossover design to investigate single-dose pharmacokinetics while reducing interindividual differences. The report ${ }^{11}$ showed that after a single oral dose of 0.25 and $0.5 \mathrm{mg}$ roflumilast, the $C_{\max }$ and $\mathrm{AUC}_{\text {inf }}$ of roflumilast and roflumilast $N$-oxide increased along with the dose of the drug. In our study, after single oral administration of $0.25,0.375$, and $0.5 \mathrm{mg}$ of roflumilast, the $C_{\max }$ values were $6.38,9.24$, and $12.50 \mathrm{ng} \mathrm{mL}^{-1}$ and the $\mathrm{AUC}_{\text {inf }}$ values were $33.80,48.7$, and $65.10 \mathrm{~h} \mathrm{ng} \mathrm{mL}^{-1}$ for roflumilast, respectively, while the $C_{\max }$ values were $6.74,10.4$, and $14.7 \mathrm{ng} \mathrm{mL}^{-1}$ and $\mathrm{AUC}_{\text {inf }}$ values were 333.0, 493.0, and $649.0 \mathrm{~h} \mathrm{ng} \mathrm{mL}^{-1}$ for roflumilast $N$-oxide, respectively, confirming the linear pharmacokinetic characteristics of the drug. The $C_{\max }$ of roflumilast was attained within 1.0 hours in healthy volunteers and the $\mathrm{AUC}_{\text {inf }}$ of roflumilast $\mathrm{N}$-oxide is around 10 times more than that of roflumilast, which is in accordance with the previous literature. ${ }^{19}$

It appears that after single oral administration of roflumilast, the degree of roflumilast exposure in Chinese patients was slightly higher than that in the foreign population. ${ }^{11}$ Population pharmacokinetic models have demonstrated 


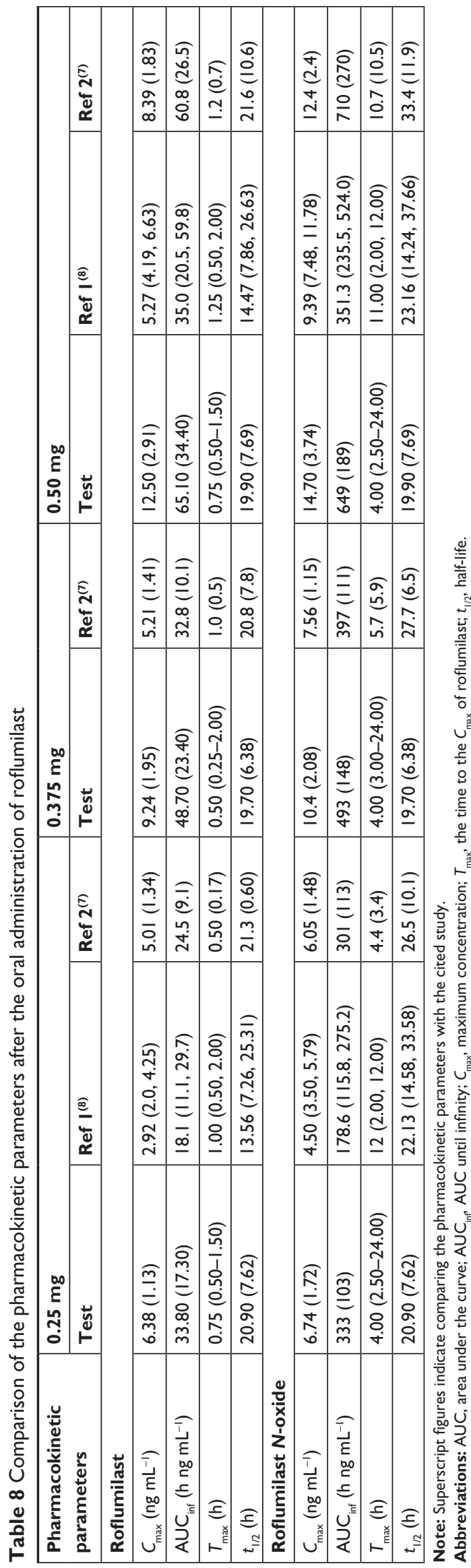

the interracial variability in exposure to roflumilast and roflumilast $\mathrm{N}$-oxide between Caucasians and other racial populations (African Americans, Hispanics, and Japanese) ${ }^{20}$ The racial differences in drug pharmacokinetics can be caused by biological factors (weight and genetics) or nonbiological factors..$^{21}$ Thus, it is necessary to explore the interracial variability of exposure to roflumilast and roflumilast $\mathrm{N}$-oxide between Chinese individuals and Caucasians. The recommended roflumilast dose of $0.5 \mathrm{mg}$ once daily was approved by the US Food and Drug Administration and the European Medicine Agency. ${ }^{22}$ However, with reference to the prescribing information for DALIRESP ${ }^{\circledR}$ (roflumilast), ${ }^{6}$ some clinicians recommend that the roflumilast dose for Chinese patients should be $<0.5 \mathrm{mg} .{ }^{18}$ Table 7 shows that the $\mathrm{AUC}_{\mathrm{inf}}$ of roflumilast and roflumilast $N$-oxide in Chinese patients was higher than those in Caucasians at the same doses $(0.25$ and $0.5 \mathrm{mg}$ ). After oral administration of $0.375 \mathrm{mg}$ roflumilast, the peak and systemic exposure to roflumilast and roflumilast $\mathrm{N}$-oxide in Chinese patients were similar to that observed in Caucasians administered $0.5 \mathrm{mg}$ roflumilast, implying that the dose of $0.375 \mathrm{mg}$ might be more appropriate for Chinese COPD patients. ${ }^{11}$ Thus, the $0.375 \mathrm{mg}$ dose was used for the multiple-dose study, considering the safety.

The results of the present study showed that most of the major pharmacokinetic parameters of roflumilast and roflumilast $N$-oxide did not statistically differ between males and females, with slightly higher levels of roflumilast $C_{\max }$ and roflumilast $N$-oxide $\mathrm{AUC}_{0-24 \mathrm{~h}}$ being observed in healthy female subjects than in male subjects.

The most common (more than 2\%) adverse reactions of roflumilast tablets (DALIRESP) are diarrhea, weight loss, nausea, headache, back pain, influenza, insomnia, dizziness, and loss of appetite. In this study, when healthy volunteers were administered a single oral dose and multiple oral doses of roflumilast, the major AEs were dizziness (53.8\%), nausea (53.8\%), diarrhea (30.8\%), headache (23.1\%), upper respiratory tract infection (23.1\%), elevated creatine kinase level (15.4\%), and elevated total bilirubin level (15.4\%). Some subjects also showed loss of appetite, fatigue, chest tightness, and right lower back pain, which was consistent with the description in the drug instructions. Except for the severe diarrhea that occurred in one subject and the acute gastroenteritis, which was moderate and occurred in one subject, the other AEs were mild. In a previous report ${ }^{11}$ including 19 subjects, 2 subjects exited the study because of AEs such as erectile dysfunction, visual flicker, and blurred vision. A total of 15 subjects reported 59 AEs after receiving $0.5 \mathrm{mg}$ roflumilast, with the most common AEs being headache 
(46.7\%), nausea (20\%), and abdominal discomfort $(20 \%)$. Thus, the results presented in the literature were consistent with those obtained in our paper.

It is worth mentioning that our study only included 12 volunteers, which a drawback. Second, reasonable markers should be used to describe dose-response, and the results obtained remain to be tested in patients with COPD and asthma, because healthy volunteers are not representative of a patient population. Finally, the influence of renal impairment on the pharmacokinetics of oral roflumilast in Chinese subjects should be studied.

\section{Conclusion}

Roflumilast was safe and well-tolerated in healthy Chinese volunteers and showed linear characteristics for $C_{\max }$ and AUC values at single doses ranging from 0.25 to $0.5 \mathrm{mg}$. No significant sex differences were observed in the pharmacokinetic parameters of roflumilast and roflumilast $N$-oxide.

\section{Acknowledgments}

We thank Xin Zheng and Xinge Cui for providing samples determination assistance. This study was supported by Pharmaceutical Preparation Optimization and Early Clinical Evaluation Engineering Technology Research Center of Hunan Province (No 2015TP2005) and Hunan Natural Science Foundation (2017JJ3464).

\section{Disclosure}

The authors report no conflicts of interest in this work.

\section{References}

1. Karish SB, Gagnon JM. The potential role of roflumilast: the new phosphodiesterase-4 inhibitor. Ann Pharmacother. 2006;40(6): 1096-1104.

2. Taegtmeyer AB, Leuppi JD, Kullak-Ublick GA. Roflumilast - a phosphodiesterase-4 inhibitor licensed for add-on therapy in severe COPD. Swiss Med Wkly. 2012;142:w13628.

3. Pinner NA, Hamilton LA, Hughes A. Roflumilast: a phosphodiesterase-4 inhibitor for the treatment of severe chronic obstructive pulmonary disease. Clin Ther. 2012;34(1):56-66.

4. Spina D. Phosphodiesterase-4 inhibitors in the treatment of inflammatory lung disease. Drugs. 2003;63(23):2575-2594.

5. Lipworth BJ. Phosphodiesterase-4 inhibitors for asthma and chronic obstructive pulmonary disease. Lancet. 2005;365(9454):167-175.

6. FDA. DALIRESP (roflumilast) tablets (Initial U.S. Approval: 2011). Available from: http://www.accessdata.fda.gov/drugsatfda_docs/ label/2015/022522s006lbl.pdf. Accessed March 31, 2015.
7. Susuki-Miyata S, Miyata M, Lee B-C, et al. Cross-talk between PKA-C $\beta$ and 655 mediates synergistic induction of PDE4B by roflumilast and NTHi. Proc Nat Acad Sci. 2015;112(14):E1800-E1809.

8. Hermann R, Nassr N, Lahu G, et al. Steady-state pharmacokinetics of roflumilast and roflumilast $N$-oxide in patients with mild and moderate liver cirrhosis. Clin Pharmacokinet. 2007;46(5):403-416.

9. Hauns B, Hermann R, Hünnemeyer A, et al. Investigation of a potential food effect on the pharmacokinetics of roflumilast, an oral, once-daily phosphodiesterase 4 inhibitor, in healthy subjects. J Clin Pharmacol. 2006;46(10):1146-1153.

10. Li Q, Wang Y, Liu L, Ma P, Ding L. Pharmacokinetics of roflumilast and its active metabolite roflumilast $N$-Oxide in healthy Chinese subjects after single and multiple oral doses. Eur J Drug Metab Pharmacokinet. 2017;42(3):371-381.

11. Bethke TD, Böhmer GM, Hermann R, et al. Dose-proportional intraindividual single- and repeated-dose pharmacokinetics of roflumilast, an oral, once-daily phosphodiesterase 4 inhibitor. J Clin Pharmacol. 2007;47(1):26-36.

12. World Medical Association. World Medical Association Declaration of Helsinki: ethical principles for medical research involving human subjects. JAMA. 2013;310(20):2191-2194.

13. European Agency for the Evaluation of Medicinal Products (EMEA). International Conference on Harmonisation World Health Organization. Guideline for Good Clinical Practice [EMEA Web site]. ICH topic E 6 (R1). Geneva, Switzerland: WHO; 2002. Available from: http://www. emea.europa.Eu/pdfs/human/ich/013595en.pdf. Accessed September 26, 2007.

14. State Food and Drug Administration. Good Clinical Practice Guideline. Available from: http://www.sda.gov.cn/WS01/CL0053/24473.html. Accessed August 6, 2003.

15. Cui X, Huang J, Zheng X. Simultaneous determination of roflumilast and its metabolite in human plasma by LC-MS/MS: Application for a pharmacokinetic study. J Chromatogr B Analyt Technol Biomed Life Sci. 2016;1029-1030:60-67.

16. Hurst JR, Vestbo J, Anzueto A, et al; Evaluation of COPD Longitudinally to Identify Predictive Surrogate Endpoints (ECLIPSE) Investigators. Susceptibility to exacerbation in chronic obstructive pulmonary disease. N Engl J Med. 2010;363(12):1128-1138.

17. Bateman ED, Izquierdo JL, Harnest U, et al. Efficacy and safety of roflumilast in the treatment of asthma. Ann Allergy Asthma Immunol. 2006;96(5): 679-686.

18. Mackay AJ, Patel ARC, Singh R, et al. Randomized double-blind controlled trial of roflumilast at acute exacerbations of chronic obstructive pulmonary disease. Am J Respir Crit Care Med. 2017;196(5): 656-659.

19. Lahu G, Hünnemeyer A, Diletti E, et al. Population pharmacokinetic modelling of roflumilast and roflumilast $N$-oxide by total phosphodiesterase- 4 inhibitory activity and development of a population pharmacodynamic-adverse event model. Clin Pharmacokinet. 2010; 49(9):589-606.

20. Lahu G, Nassr N, Hünnemeyer A. Pharmacokinetic evaluation of roflumilast. Expert Opin Drug Metab Toxicol. 2011;7(12):1577-1591.

21. Roflumilast (Daliresp) for COPD. Med Lett Drugs Ther. 2011;53: 59-60. Available from: https://secure.medicalletter.org/articleshare $\mathrm{a}=1369 \mathrm{~b} \& \mathrm{p}=$ tml\&title $=$ Roflumilast $\% 20$ (Daliresp) $\% 20$ for $\% 20$ COPD\&cannotaccesstitle $=1$. Accessed November 6, 2018.

22. Kim K, Johnson JA, Derendorf H. Differences in drug pharmacokinetics between East Asians and Caucasians and the role of genetic polymorphisms. J Clin Pharmacol. 2004;44(10):1083-1105. 


\section{Publish your work in this journal}

Drug Design, Development and Therapy is an international, peerreviewed open-access journal that spans the spectrum of drug design and development through to clinical applications. Clinical outcomes, patient safety, and programs for the development and effective, safe, and sustained use of medicines are the features of the journal, which has also been accepted for indexing on PubMed Central. The manuscript management system is completely online and includes a very quick and fair peer-review system, which is all easy to use. Visit http://www.dovepress.com/testimonials.php to read real quotes from published authors.

Submit your manuscript here: http://www.dovepress.com/drug-design-development-and-therapy-journal 